\title{
THE READINESS OF INTEGRATING SUSTAINABLE DEVELOPMENT INTO BIOLOGY TEACHER EDUCATION PROGRAM
}

\author{
Shakinaz Desa*, Mai Shihah Abdullah, Nurul Huda Ab Mutalib, Rosnidar Mansor \\ Universiti Pendidikan Sultan Idris, Malaysia \\ *e-mail: shakinaz@,fsmt.upsi.edu.my
}

\begin{abstract}
The idea of sustainability has long become a regulatory concept applied in national and international policies worldwide. This study aimed to investigate the understanding, attitude, and behavior levels towards education and sustainable development among key players in teacher education program, particularly in Biology, including learners, educators, administrators, and supporting personnel from the Biology Department of a public university in Malaysia. A set of validated questionnaires was administered online to 61 participants. A semi-structured interview was carried out with 9 randomly selected participants. An expert in the curriculum was referred to in search of integration of sustainable development in the current pro forma. Readiness was found highest in behavior, followed by both understanding and attitude. Courses in the Biology Teacher Education program need a well-planned integration to meet the sustainable development concept. Thus, we recommend readiness analysis as a part of the requirement in sustainable development-integrated curriculum design. The implication of this study is, a strategic action plan to interconnect the players' readiness and curriculum design is a new imperative element in the teacher education program.
\end{abstract}

\section{Keywords: Biology, sustainable development, teacher education.}

\section{KESIAPAN TERINTEGRASI PEMBANGUNAN BERKELANJUTAN KE DALAM PROGRAM PENDIDIKAN GURU BIOLOGI}

\begin{abstract}
Abstrak: Ide tentang keberlanjutan telah lama menjadi konsep dalam peraturan diterapkan sebagai kebijakan di tingkat nasional dan internasional seluruh dunia. Penelitian ini bertujuan untuk menemukan tingkat pemahaman, sikap, dan kebiasaan terhadap pendidikan dan pengembangan berkelanjutan antar pelaku utama dalam program pendidikan guru, khususnya Biologi, terdiri atas peserta didik, pendidik, admisi dan personil pendukung dari Departemen Biologi di sebuah universitas di Malaysia. Satu set perangkat kuesioner yang tervalidasi dikumpulkan secara daring diberikan kepada 61 orang responden. Wawancara semiterstruktur dilakukan dengan 9 responden terpilih secara acak. Pakar dalam kurikulum dirujuk untuk mencari integrasi pembangunan berkelanjutan yang sesuai dengan capaian masa kini. Kesiapan ditemukan paling tinggi dalam perilaku, diikuti oleh pemahaman dan sikap. Mata kuliah dalam program Pelatihan Guru Biologi membutuhkan integrasi yang baik dan terencana untuk memenuhi konsep pembangunan berkelanjutan. Selanjutnya kami merekomendasikan analisis kesiapan digunakan sebagai bagian dari persyaratan dalam desain pola kurikulum yang terintegrasi pembangunan berkelanjutan. Implikasi dari penelitian ini adalah perencanaan aksi strategis untuk menghubungkan kesiapan pelaku dan desain kurikulum merupakan elemen penting baru dalam program pendidikan guru.
\end{abstract}

Kata Kunci: Biologi, pembangunan berkelanjutan, pendidikan guru.

\section{INTRODUCTION}

The idea of sustainability has long become an integral, regulatory concept applied in national and international policies worldwide. To date, discussions of sustainability and sustainable development (SD) do not restrict to environmental issues, but also include the development of humankind and society with regards to the ecological, the economic, and the social as the minimum dimension (Reed, 2019). The United Nations member renewed their commitment to global development by adopting the 2030 Agenda for Sustainable Development, which consists of 17 sustainable development 
goals. Education won't satisfy its capability to drive progress except if there is more prominent cooperation across areas and, learning and training frameworks are completely embraced supportable turn of the events (MENA Report, 2016).

The concept of SD Goal 4 is mainly for education to improve learning approaches and outcomes in order to tackle the global challenges. Thus, educators should be an active key player to facilitate understanding and awareness of sustainability in school children including in early childhood education. Hence, teachers must have the knowledge, awareness, competency, and right behavior to create learning opportunities for their students. On that note, teacher education institutions must play greater and active roles to train student teachers with the necessary skills. For instance, critical thinking skills (Straková \& Cimermanová, 2018), problemsolving skills (Richter-Beuschel \& Bögeholz, 2020), ecological literacy (Riyadi, Prayitno, \& Karyanto, 2018), futures-thinking, valuesthinking, strategic-thinking, and interpersonal competency (Brundiers et al., 2021). Thus, in higher education, the approach can be via teaching the components of sustainability or by using sustainability to achieve learning outcomes (Mika, 2017).

A teacher has a vital role in achieving SDGs in education. Hence, how we prepare teacher education is crucial. We need to train student teachers and help them acquire those vital skills that they are going to apply in their classrooms during their professional practice. However, evidence showed that most sustainability issues are discussed only in the relevant subject areas (Sunthonkanokpong \& Murphy, 2019), thus the coverage of sustainable development principles becomes limited. As a matter of fact, training institutions could address the issues through other enrichment programs, such as Science fair, Culture fair, Plant-A-Tree, and "Plogging" activity.

To promote $\mathrm{SD}$, education reformation is always the key tool in all areas of formal and informal education across all disciplines. Sustainable development is one of many skills proposed as core literacies for every citizen. The most appropriate way to provide such literacy is through all levels of education, both formal and informal which include the higher education institution (HEI) as highlighted in the Rio 20 conference due to the important role of HEI in achieving sustainability in development (Cheang, So, Zhan, \& Tsoi, 2017). Education for sustainable development (ESD) focuses on the learning facets that refine the sustainability transition. These facets include future education, citizenship education, health education, education for sustainable consumption, education for protecting and managing natural resources, gender quality and respect for human rights, and education for a culture of peace (Wahono \& Chang, 2019).

In fulfilling the needs of the present generation, all facets of life for the future generation must always be on the monitor for their sustainable future (Ariffin \& Foo, 2020; Bezeljak, Scheuch, \& Torkar, 2020). ESD therein seeks to balance the well-being of the human, economic, social, and cultural traditions with respect for the natural resources on Earth (Wahono \& Chang, 2019). To achieve this goal, the present educational curriculum has to be revisited and revamped. This also applies to the curriculum of higher-level education, especially the ones to produce future teachers who should be capable to deliver SD through ESD. This calls for systematic training for the teachers, where, future teachers do not only have to be aware of specific critical issues of human survival in future development but also to equip themselves by mastering the key competencies which can be applied to a variety of situations within the teaching-learning process (Straková \& Cimermanová, 2018).

We identified the challenges in developing an ESD integrated curriculum. It is not an easy task; thus, this effort requires cooperation from many aspects and different changing agents. In HEI, there are various types of identified changing agents and these agents are referred to as players in the context of this study. At the educator's level, several studies conducted demonstrate that teachers are with a positive attitude concerning implementing various ESD related issues i.e., ethical decision skills (Husamah, Pantiwati, \& Hudha, 2017), outdoor education (Jeronen, Palmberg, \& Yli-Panula, 2017), physics education (Nasri, Nasri, \& Abd Talib, 2020) and engineering (Tang, 2018). A study showed that professional knowledge has a strong and positive impact on teaching practice 
and professional engagement (Manasia, Ianos, \& Chicioreanu, 2020). The study pointed out that, lesson planning and design are among important indicators to provide readiness. Thus, a strong curriculum that applies integration of SD should be able to lead the whole academic community towards ESD. Another strong factor to readiness is self-management. This skill is considered to have potential in supporting the effectiveness of both teaching and learning during their professional practices in school.

In this study, we identified key players in Biology Teacher Education Program (BTEP) as learners, educators, administrators, and supporting personnel. The curriculum integration needs a meticulous design to connect cognitive, affective, and psychomotor skills with the sustainable development concept. Thus, the players too, must have sustainable development knowledge, carry similar values, and practice the same actions. However, the readiness in teacher training is vital to ensure teachers are able to implement ESD in school using appropriate approaches. Anyolo, Kärkkäinen, \& Keinonen (2018) stated that, the transfer of perception into practical activities needs a holistic curriculum development that should not have barriers between teachers' internal and personal traits, and pedagogical knowledge.

Therefore, we need to identify their current understanding, attitude, and behavior towards SD and ESD, thus indicating their readiness for the sustainable development integrated curriculum. The objective of this study was to determine their readiness on SD and ESD and, to detect issues and challenges in their perspectives.

\section{METHODS}

To determine the understanding, behavior, and attitude on SD and ESD, we applied four SD pillars in this study namely, environment, economy, social, and culture. Whilst, ESD encompassed future education, citizenship education, health education, education for sustainable consumption, education for protecting and managing natural resources, gender quality and respect for human rights, and, education for a culture of peace. The study was carried out in three phases. Phase 1 focused on the gap analysis via a bachelor degree final year research project entitled "Awareness of Education for Sustainable Development (ESD) Among Teachers in Science". Phase 2 involved the construction of instruments and identification of population using the approach of purposive sampling (Etikan, Musa, \& Alkassim, 2015). Whilst, Phase 3 consisted of field testing and data analysis. We focused the research on readiness that is related to understanding, attitude, and behavior. These focuses are further investigated to the four pillars. Figure 1 shows the connection of the readiness criteria, pillars, and BTEP. This study focuses on the elements in the gray box.

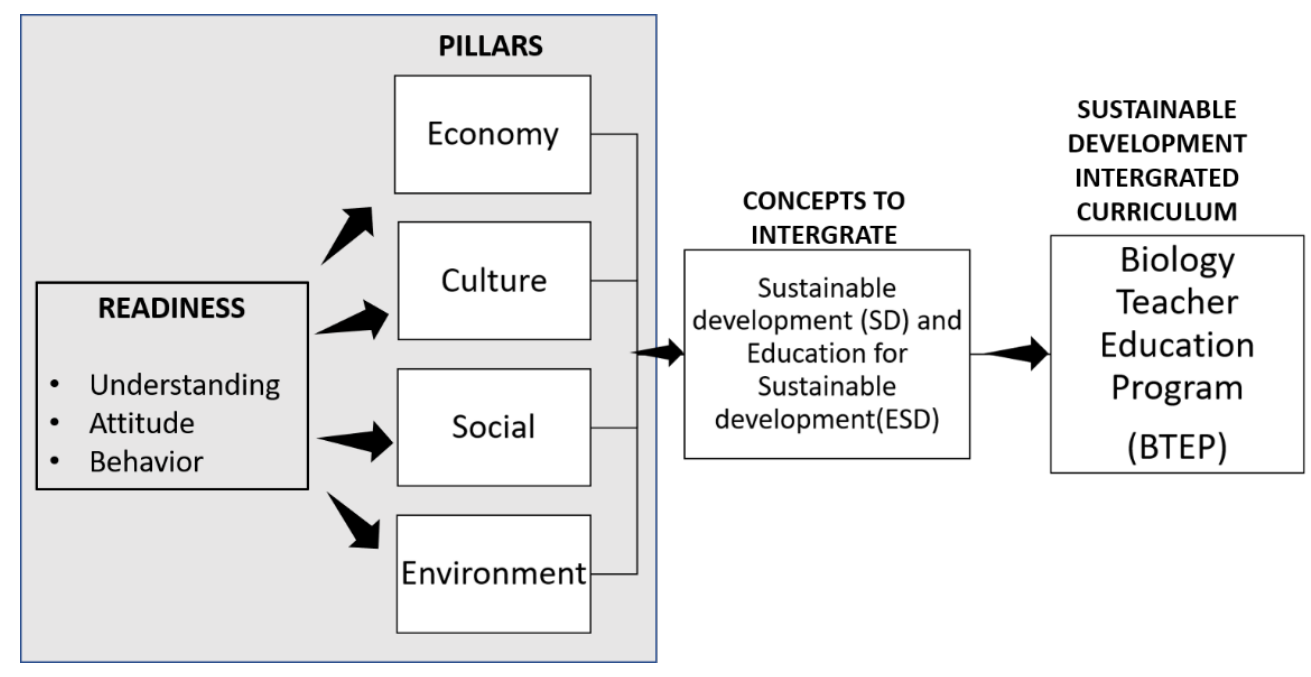

Figure 1. Research Focuses on the Integration of SD and ESD Concepts into BTEP 
We constructed an online questionnaire that consists of 48 items with a 5-point Likert scale. Questions were developed according to a guideline by UNESCO and adapted from previous studies to meet the local context (Nagata, 2017). The 5 agreement scales are; strongly disagree, disagree, do not know, agree, and strongly agree. Both SD and ESD-related statements were constructed to meet the four pillars and we focused on three criteria: understanding, attitude, and behavior. Fifteen items were constructed to determine the understanding of SD and ESD, 16 items on attitude towards SD and ESD, and 17 items on how they behave towards SD and ESD. We carefully distributed the item statements into the pillar of each category for balanced distribution.

A pilot study was conducted to determine the reliability of the instrument to another group of 51 participants from the same players' communities. The analysis of internal consistency showed Cronbach's $\alpha$ as .954. Therefore, the instrument is highly reliable and was employed in the field study. Participants were selected based on their strong involvement in BTEP. The field study was administered to 61 participants in the Department of Biology. All participants consisting of Biology Education learners, Biology educators, Biology educators cum administrators, and one supporting personnel from the Department of Biology. All participants were highly involved in the educational activities which mainly on the BTEP. We analyzed the data using descriptive statistics. We classified the level of agreement as in Table 1.

Table 1. Level of Agreement

\begin{tabular}{ll}
\hline Level of Scale & Percentage of Agreement \\
\hline Very high & $80-100$ \\
High & $60-79$ \\
Medium & $40-59$ \\
Low & $20-39$ \\
Very low & $1-20$ \\
\hline
\end{tabular}

A semi-structured interview was carried out with 9 randomly selected BTEP players for purposive intention and as recommended due to the small sample size (Saunders \& Townsend, 2016; Vasileiou, Barnett, Thorpe, \& Young, 2018). We administered seven validated questions under four themes 1) concept of Education for Sustainable development; 2) application of ESD in daily life; 3) the role of higher education institution's (HEI) in ESD; and 4) challenges to the effective implementation of ESD.

Each of the interview sessions was carried with ethical approval and participant consents were obtained. The data collected for each interview session was transcribed and analyzed. Nine participants were coded each as Respondent A to I. We also carried out an expert's feedback on the potential of ESD integration/embedding on the current courses for the program. We provided all fifteen-course pro forma documents to the expert to evaluate and decide the score of the integration if any. The expert scored 0 value for no integration/poor, 2 - fair, 3 - average, 4 good, and 5- excellent.

\section{FINDINGS AND DISCUSSION Findings \\ The Understanding Level of SD and ESD}

Participants' responses to statements are indicating their overview understanding of SD and ESD. Figure 2 shows, respondents strongly agree with both SD-related statements (48.2\%) and ESD-related statements (57.4\%). The distribution shows a high percentage of understanding for both SD and ESD.

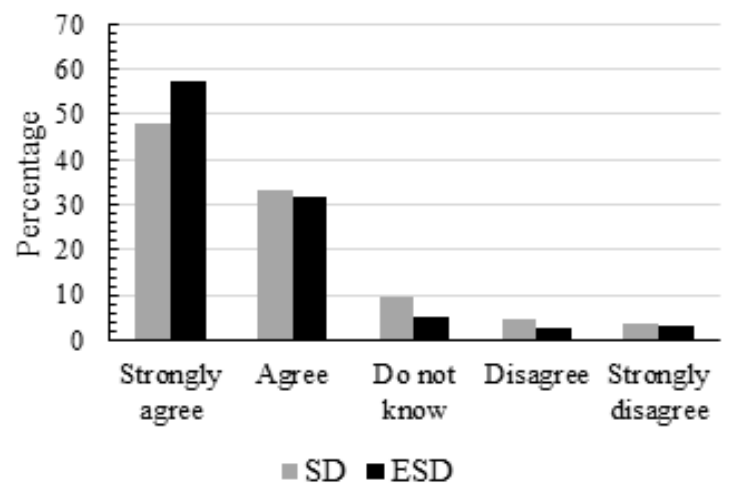

\section{Figure 2. Percentage of Understanding Criteria Agreement on SD and ESD}

The SD-related statement under the Social category scored the very high level at $91.8 \%$. Participants agreed that "Respecting human rights is necessary for sustainable development". On the ESD-related statement under the Culture category, "Biology education should promote equal opportunities for males and females towards sustainable development" scored the very high-level agreement at 95.1\%. The same score was detected in the Social 
category, "Biology education should encourage the connection between local and global issues". These results inform us that the university community prioritizes human rights in education for sustainable development, which combines social and cultural elements.

However, the SD-related statement "Environmental protection is more important than development" of the economic pillar, and the ESD-related statement "When we use natural resources in excess for lab experiment, it will affect the well-being of future generations" of the environment pillar, were most disagreed by the participants $(14.8 \%)$.

\section{The Attitude level of SD and ESD}

The attitude score pattern is similar to the understanding score (Figure 3). We observed, in general, $45.9 \%$ of participants strongly agreed with SD-related statements, and $51.4 \%$ of participants to ESD-related statements.

The ESD-related attitude statement, under the social pillar, was found the highest level of agreement. Among all attitude statements, "Biology education should ensure that people in the future experience the same quality of our life now" scored the very high level (96.7\%). Three SD-related statements on attitude were each scored highest at $95.1 \%$, "I believe that all plants and animals have as much right as we exist", "I must participate more in educating community activities on sustainable development" and, "I think Malaysian government should provide more financial aid to encourage more people to make the shift to environmentally friendly vehicles" for the environment, social and economic pillar, respectively. These results informed a coherence between understanding and attitude criteria (see Figure 3). Both criteria have a high-level agreement in the social pillar.

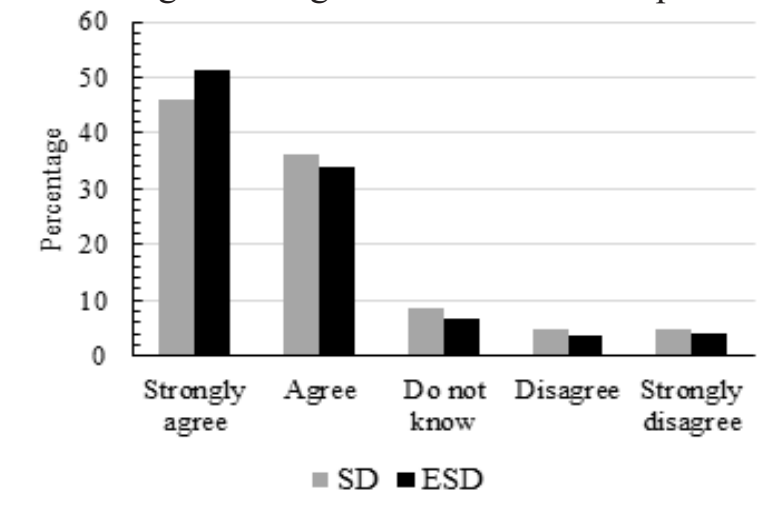

Figure 3. Percentage of Attitude Criteria Agreement on SD and ESD
We also found that the most disagreement for SD-related statement "When we consume more natural resources than we need, it will not cause any danger to the health and well-being of people in the future" and under the social pillar and environment pillar for ESD-related statement "In my opinion, educators have no right to alter the environment to meet their needs" both scored low-level at $37.7 \%$ and $27.9 \%$ respectively.

\section{The Behavioral Level of SD and ESD}

The behavior criteria score pattern shows an almost similar pattern to the Understanding and Attitude criteria. However, we observed a non-significant difference in score between the Strongly Agree and Agree scale (Figure 4). Participants responded the highest to the SDrelated statement under the culture pillar at $96.7 \%$, which agreed to "I treat my friends from different cultural backgrounds with the same respect". In the ESD-related statement, 91.8\% response was observed for "I educate my family to reduce wastage of water and electricity", under the environment pillar. Both behaviors indicated that the practice is already in their belief. This would aid the execution of the integration of SD and ESD in BTEP.

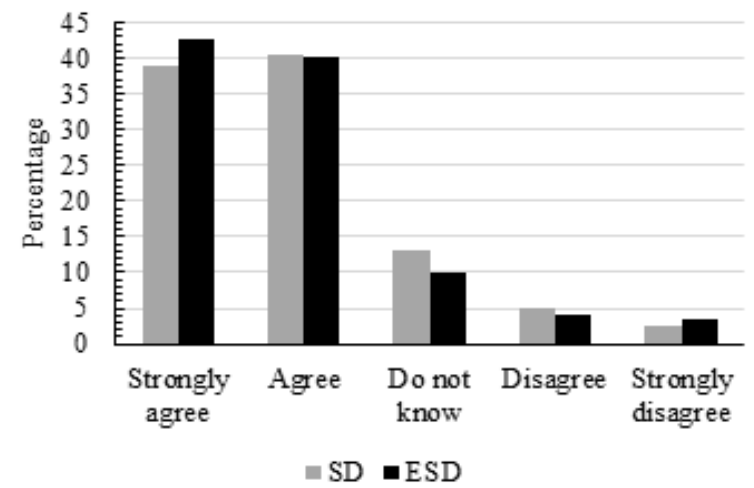

\section{Figure 4. Percentage of Behavior Criteria} Agreement on SD and ESD

SD practice needs continuous action to make it a belief. Our evidence showed that the majority of participants did not practice secondhand good purchasing. This culture may not yet circulate in society for many reasons. We observed a medium-level agreement at 50.8\% for "I encourage people to purchase second-hand goods over the internet or in a shop". Thus, the whole society must be promoted with this idea to create a trend in society to become a norm. However, an ESD-related statement on the 
economy showed a different view. "I encourage not to buy fruits and vegetables in plastic bags" statement was scored at $68.9 \%$, a high-level agreement

In general, this study discovered the Very high to High-level agreement of participants towards SD and ESD. Table 2 summarizes the findings on the level of agreement versus the SD pillars towards the criteria. The gray color shows that there was a Very high - High agreement on understanding for both SD and ESD towards the economy and social, whereas, attitude criteria had a Very high - High agreement level for economy and culture, and behavior criteria showed a High-level agreement in SD for all pillars except a Medium in ESD for the economy.

Table 2. Profile of Readiness Criteria Agreement against SD Pillars

\begin{tabular}{|c|c|c|c|c|c|c|c|c|}
\hline \multirow{3}{*}{ Criteria } & \multicolumn{8}{|c|}{ Pillar } \\
\hline & \multicolumn{2}{|c|}{ Economy } & \multicolumn{2}{|c|}{ Culture } & \multicolumn{2}{|c|}{ Social } & \multicolumn{2}{|c|}{ Environment } \\
\hline & SD & ESD & SD & ESD & SD & ESD & SD & ESD \\
\hline $\begin{array}{c}\text { Understanding } \\
\text { Attitude }\end{array}$ & & & & & & & & \\
\hline Behavior & & & & & & & & \\
\hline
\end{tabular}

Color indicator: Gray: Very high- High level; White: Medium

\section{ESD Practices}

The interview sessions were transcribed and analyzed accordingly, and clustered into four themes: the concept of ESD, application of ESD, the role of higher education institute (HEI) in ESD, and challenges to the effective implementation of ESD. The analysis for the Concept of the ESD theme discovered that the interpretations varied on many levels. One respondent provided the closest to the original interpretation of ESD;

“...to empower students with skills, knowledge, attitude, and value, and use them to sustain life in this world. To teach a new generation about the environment." - (Respondent, $\mathrm{H}$ )

Respondent, E interpreted the ESD concept to teach students to apply what they learned in their lives, while Respondent, F only stated that ESD is to improve the education system so that it can produce responsible individuals. Respondent, $\mathrm{G}$ also did not clearly state the meaning of ESD from her perspective, instead, she stated that she heard of it from a colleague and since then, did some readings on ESD. About $55.6 \%$ of the respondents were unfamiliar with the term 'sustainability and hence, unable to give accurate interpretations of education for sustainable development (ESD).

As for the second theme: application of ESD, most of the responses received were closely tied to the environmental pillar of SD/ESD. Respondents, H, and E had a good application of ESD in life by engaging with the surrounding communities. The engagement included knowledge transfer and hands-on experience to the community regarding the importance of biodiversity. Respondent, E also shared that during the teaching and learning process, he would occasionally relate the current phenomena or environmental issues with the syllabus taught to help students understand more. Respondents, A and I were putting more focus on waste management and use fewer materials, while Respondent, $G$ focused only on the theory without application. Only 33.3\% of the respondents were unable to provide their application of ESD in life.

In the third theme, the role of HEI in ESD included responses for two items, which are the ESD-related policy in university and the role of the department in achieving sustainability. There was not clearly stated policy on SD/ESD being done. However, Respondent E, added the educators especially should feel obliged to gain knowledge about it. Respondents E, and $\mathrm{H}$ however, stated few external policies that are indirectly related to SD/ESD such as Environmental Impact Assessment (EIA), National Policy on Biological Diversity, and National Forestry Policy. Respondent, I elaborated that she was unaware of such policy, however, she did notice the university's aim for UI-Green metric World University Ranking which is an international ranking system of universities based on their environmental performance. 
Respondents, A, I, and E gave opinions that there should be more exposure to ESD through talks or campaigns to make the people and the students understand and apply such knowledge in their lives, and also to transfer the knowledge to other people. Respondent, $\mathrm{H}$ provided quite an excellent opinion regarding this matter. He stated there should be a review of the curriculum and courses offered by the department. He also suggested the programs offered by the Biology department to be revamped and include the element of ESD in every course. It has to be reviewed from time to time and make it compulsory.

\section{Issues and Challenges}

The fourth theme is the challenges to the effective implementation of SD in the Biology Teacher Education program. The responses were collected and analyzed into several categories: knowledge on ESD, application of the knowledge, integrated curriculum, educator's preparedness, acceptance from BTEP players, and enforcement of the integration. The knowledge of ESD could be further detailed into two codes, which are exposure and clear understanding. Majority of the respondent was unable to provide a correct interpretation of ESD, responded that there was little to none exposure about SD/ESD from the department. Respondent, I added that a clear understanding of SD/ESD is equally important as the exposure to optimizing the knowledge on this matter.

"The most basic issue is actually from the understanding of the sustainable development itself... we need a clear understanding of how do we carry out sustainable development..." (Respondent, I)

In the application of the knowledge strategy, the analysis was also detailed into two codes: knowledge transfer and implementation in life. Respondent, E emphasized the knowledge transfer from learners to their surroundings and to constantly remind them so that the knowledge on SD/ESD obtained will continuously spread to all. Another concern is the implementation of the knowledge in real life which also requires constant emphasis and a reminder to not only the learners but also all players. Respondent, I raised a question of whether we teach the players just for the sake of knowledge or we genuinely want them to apply the knowledge in their daily lives.

The next barrier is the integrated curriculum, detailed into three codes, namely local context, time constraint, and cost. As many are still in the dark regarding SD/ESD, respondents voiced out that there will be difficulties to match the new curriculum to the local context of SD/ESD, and revamping the existing curriculum will surely require time and cost. As for the category educator's preparedness, this category was further detailed into three codes, which are proper training, guidelines of ESD integration, and best-suited teaching strategy. Respondent, $\mathrm{H}$ shared an opinion that an ESD-dedicated guideline must be created for the educators, together with proper training so that the educators are confident to deliver instruction in their classrooms.

Another barrier towards successful implementation is the acceptance of the future of BTEP players which is then further detailed into three codes: varied responses, willingness to change, and readiness of the learners. The responses stated that there will be positive and negative acceptance out of the implementation, and these are all associated with the attitude and education levels of the players. The final barrier that was able to be extracted from the responses is the enforcement, which involves the players with authority such as the department that should ideally be more active and constantly ongoing.

\section{Expert Reviews}

All the courses pro forma for undergraduates under the Biology department were submitted for review by an ESD expert. The expert rated the pro forma from $0 / 4$ (poor) to $4 / 4$ (excellent integration). Figure 5 summarized the expert feedback on the integration of existing courses. According to the researchers' point of view, there was little to no integration of $\mathrm{SD} /$ ESD in the current curriculum. However, upon receiving comments from the expert, three out of fifteen courses pro forma are good examples of the integration and/or embedding of SD/ESD in the current curriculum. Five pro forma received ratings of $2 / 4$ to $3 / 4$, four pro forma received $1 / 4$ ratings and two pro forma received $0 / 4$ ratings. The ratings were given based on the Course Learning Outcome (CLO) whether it includes integration/embedding of ESD in it.

Examples of the expert's comment for 
4/4 ratings are "Embedded ESD element seems addressed in all four CLOs. Good example." and "Course conducted is direct to integrate/embed ESD immensely." Meanwhile, the examples of comments for $0 / 4$ ratings are as follows "Supposedly ESD should transpire deeply but has not been tackled enough in the CLOs" and "Recommend looking further for more critical and innovative CLOs." The analysis of the comments from the expert found $28.6 \%$ of the present courses pro forma are already integrated or embedded between excellent-good categories (see Figure 5).

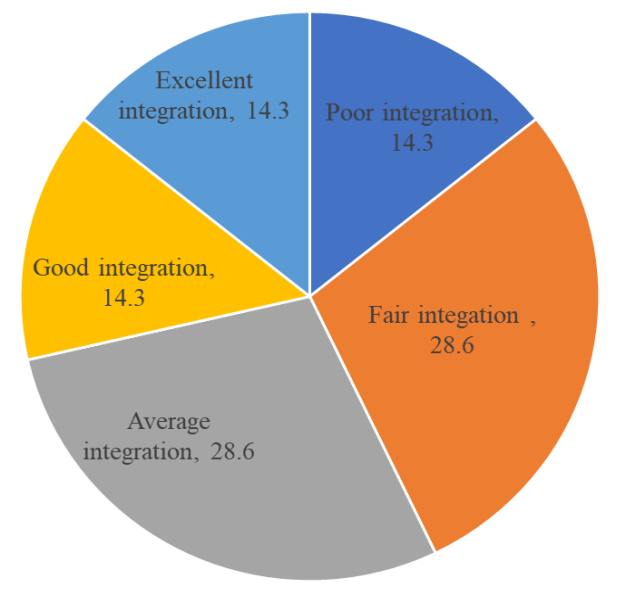

Figure 5. Composition of SD/ESD Integration Found in Current BTEP

\section{Discussion}

This study is not only to determine the readiness of integrating sustainable development into BTEP but beyond it. We found that efforts for education right around the world have somehow unified the idea of both SD and ESD in the participants. we believe that SD and ESD should be the core of the program curriculum in teacher training. The curriculum should be dynamic, flexible, adaptable, and relevant throughout the era. SD and ESD will stay longer in the world, thus teacher training programs must transform synchronously with changes. However, the need for precise indicators to the changes must be developed. We suggest further work to be done in the development of indicators not only to measuring knowledge, skills, and attitudes, but also the readiness to SD and ESD. A study also agreed with the idea of having indicators at the macro, meso, and micro-level (Filho et al., 2021). The study also proposed indicators to the outputs of ESD and not merely looking at the input and process.

The idea that using natural resources will not have an effect on the future generation still exists. Even though it is at a low level, the possible impact must be reflected seriously. They observed development as important and would not be affecting future generations. This perilous idea can grow and might influence others. Thus, we can see how important education on sustainable development should be put forward. For example, we detected $18 \%$ of participants were indecisive on the SDrelated statements, "Increasing the economic well-being of the industrialized countries is less important than reducing poverty and hunger in the world". This marked the concept of SD in the participants was still unclear, thus require adequate awareness. The effective means to curb this idea from influencing others is through education at an early age. At the school level, children are more opened and easily accept the idea of SD (Suwarto, Sanjaya, \& Solihat, 2021). However, we realized that the key to instilling originates from a teacher as the curriculum delivery person. The appropriate lesson plan or design is able to develop ESD through various approaches such as technological pedagogical content knowledge (Novidsa, Purwianingsih, \& Riandi, 2021), STEM implementation (Wahono \& Chang, 2019), problem-based learning (Riyadi et al., 2018), and living laboratory (Zen, 2017). Therefore, not only ESD should be integrated in the teacher training curriculum, but also at the school level.

We ranked the agreement by the pillar according to the percentage. The analysis showed that ESD-related statements on culture, social, and environment, were ranked top three out of 15. SD-related statements on the economy pillar were at the bottom 5. This rank had informed us of the agreement imbalance of the four pillars among participants, which urged the need for SD understanding enhancement. This situation is also supported by (Riyadi et al., 2018). They applied subject-specific pedagogy based on Problem-based learning, which resulted in an increase in students' ecological literacy. Thus, proving the effectiveness of integrating the SD concept into a curriculum will improve the understanding.

We detected that the Understanding and Attitude criteria in SD need improvement 
in culture and environment pillars, but the agreement was a Very High-High in Behavior criteria. These results informed us of the importance of providing SD-based culture and environment in higher education to create cohesiveness to the behavior. On the other hand, ESD needs improvement in Attitude and Behavior, even if the Understanding scored a Very High - High level. Overall, readiness was the highest in behavior criteria, followed by understanding and attitude. These findings proved that although knowledge is provided in higher education, the impact will not be profound if the attitude and behavior are not orchestrated. Hence, the mission of SD and ESD becomes less meaningful. Despite the suggestion, at this point, we could conclude that the existence of readiness among the participants is attested.

Campaigns and policies on plastic usage by various entities can be seen around Malaysia. Food businesses such as convenience stores, wet markets, and wholesales outlets have played their roles well. It has pushed society to practice $\mathrm{SD}$, thus, integrating SD into BTEP will be much easier. We detected that the participants 'practices and beliefs are leaning towards SD. But any integration could not be done without SDbased strategic planning by HEI on curriculum revision. This is a similar effort required as reported in a higher education context (Ariffin \& Foo, 2020; Habib, Khalil, Khan, \& Zahid, 2021; Filho et al., 2021; Wu \& Shen, 2016; Lai \& Peng, 2020). However, we found that the readiness of participants for integration does not match with the current curriculum. Participants were ready for the SD integrated curriculum but the cohesiveness of the curriculum was not found. Hence, we can conclude that the role of HEI leaders is crucial in the integration of ESD in BTEP and to make a sound decisions in steering the mission and vision of an education program.

A study on Science Creative Teaching Design (SCTD) was done to enable science teachers to plan and produce flexible, practical, and feasible lesson plans and conduct teaching and learning. The findings found a thinking gap in connecting learning science and the environment (Ismail, Desa, \& Balakrishnan, 2018). The connection can be done through experience and creative teaching practices, guided by a sound curriculum. The analysis of the interview discovered that the center of the implementation is the knowledge of $\mathrm{SD} / \mathrm{ESD}$, which can be seen where most of the responses are concerned about how the educators will transfer the knowledge if some are still unable to fully grasp the definition and interpretation of $\mathrm{SD} / \mathrm{ESD}$. This concern includes the educator inservice and the future educators to-be-produced by the university. Thus, we concluded the importance of implementing SD/ESD in future education should be prioritized in BTEP.

\section{CONCLUSION}

Readiness was found in SD under the economy and social pillars, whilst ESD under the culture and environment pillar. We detected partial readiness in SD-culture, and ESDEconomy and Social. Overall, we concluded that the majority of participants were ready for changes in BTEP. However, we are concerned with the curriculum design of BTEP, which should be the main landscape for ESD. Future studies should focus on the alignment of SD pillars in designing a Biology education curriculum. This study implies that readiness and curriculum design for ESD could be used as key standards in considering SD integrated teacher education programs. However, there are limitations to the focus of this study. We highlighted only on Biology education program, which has the elements of SD in some subjects. Hence, we suggest a wider coverage of education programs, such as non-science programs, skillbased programs, and work-based programs.

\section{ACKNOWLEDGMENTS}

The authors acknowledge the financial support from Universiti Pendidikan Sultan Idris for funding the research under GPU Research code: 20180297.

\section{REFERENCES}

Anyolo, E. O., Kärkkäinen, S., \& Keinonen, T. (2018). Implementing education for sustainable development in Namibia: School teachers' perceptions and teaching practices. Journal of Teacher Education for Sustainability, 20(1), 64-81. https:// doi.org/10.2478/jtes-2018-0004.

Ariffin, F. N., \& Foo, T. F. (2020). Understanding and opinion on sustainable development among youths in higher educational 
institutions in Penang, Malaysia. Social Indicators Research, 147(2), 421-437. https://doi.org/10.1007/s11205-01902165-1.

Bezeljak, P., Scheuch, M., \& Torkar, G. (2020). Understanding of sustainability and education for sustainable development among pre-service Biology teachers. Sustainability, 12(17), 1-16. https://doi. org/10.3390/su12176892.

Brundiers, K., Barth, M., Cebrián, G., Cohen, M., Diaz, L., Doucette-Remington, S., ... \& Zint, M. (2021). Key competencies in sustainability in higher educationToward an agreed-upon reference framework. Sustainability Science, 16(1), 13-29. https://doi.org/10.1007/s11625020-00838-2.

Cheang, C. C., So, W.-M. W., Zhan, Y., \& Tsoi, K. H. (2017). Education for sustainability using a campus eco-garden as a learning environment. International Journal of Sustainability in Higher Education, 18(2), 242-262. https://doi.org/10.1108/ IJSHE-10-2015-0174.

Etikan, I., Musa, S. A., \& Alkassim, R. S. (2015). Comparison of convenience sampling and purposive sampling. American Journal of Theoretical and Applied Statistics, 5(1), 1-4. https://doi.org/10.11648/j. ajtas.20160501.11.

Filho, W. L., Levesque, V. R., Salvia, A. L., Paço, A., Fritzen, B., Frankenberger, F., ... \& Lovren, V. O. (2021). University teaching staff and sustainable development: An assessment of competences. Sustainability Science, 16(1), 101-116. https://doi. org/10.1007/s11625-020-00868-w.

MENA Report. (2016, 7 September). France: 2016 Global Education Monitoring Report launched with urgent call to prioritize education to reach SDGs. London: Albawaba. http://www. proquest.com/docview/1817552079/ abstract/766FBF309A7F41C2PQ/4.

Habib, M. N., Khalil, U., Khan, Z., \& Zahid, M. (2021). Sustainability in higher education: What is happening in Pakistan? International Journal of Sustainability in Higher Education, 22(3), 681-706. https:// doi.org/10.1108/IJSHE-06-2020-0207.

Husamah, H., Pantiwati, Y., \& Hudha, A. M. (2017). OIDDE learning model through integrated field studies abroad to develop ethical decision skills of candidate Biology teachers: Indonesian perspective. Educational Process: International Journal, 6(4), 7-19. https:// doi.org/10.22521/edupij.2017.64.1.

Ismail, N., Desa, S., \& Balakrishnan, B. (2018). Science creative teaching design for science teachers. International Journal of Academic Research in Business and Social Sciences, 8(4), 1214-1220. http:// dx.doi.org/10.6007/IJARBSS/v8-i4/4156.

Jeronen, E., Palmberg, I., \& Yli-Panula, E. (2017). Teaching methods in Biology education and sustainability education including outdoor education for promoting sustainability-A literature review. Education Sciences, 7(1), 1-19. https://doi.org/10.3390/educsci7010001.

Lai, Y. -C., \& Peng, L. -H. (2020). Effective teaching and activities of excellent teachers for the sustainable development of higher design education. Sustainability, 12(1), 28. https://doi.org/10.3390/ su12010028.

Manasia, L., Ianos, M. G., \& Chicioreanu, T. D. (2020). Pre-service teacher preparedness for fostering education for sustainable development: An empirical analysis of central dimensions of teaching readiness. Sustainability, 12(1), 166. https://doi. org/10.3390/su12010166.

Mika, J. (2017). Education in the Sustainability Development Goals (2016-2030), sustainability in the education. Journal of Applied Technical and Educational Sciences, 7(4), 43-61. https://doi. org/10.24368/jates.v7i4.10.

Nagata, Y. (2017). A critical review of Education for Sustainable Development (ESD) in Japan: Beyond the practice of pouring 
new wine into old bottles. Educational Studies in Japan, 11(0), 29-41. https:// doi.org/10.7571/esjkyoiku.11.29.

Nasri, N. M., Nasri, N., \& Abd Talib, A. A. (2020). Physics teachers' perceptions on sustainable Physics Education. Journal of Baltic Science Education, 19(4), 569-582. https://doi.org/10.33225/jbse/20.19.569.

Novidsa, I., Purwianingsih, W., \& Riandi, R. (2021). Technological pedagogical content knowledge (TPACK) prospective biology teacher in integrating education for sustainable development (ESD) in their learning planning. Journal of Physics: Conference Series, 1806(1). https://doi. org/10.1088/1742-6596/1806/1/012163.

Reed, M. G. (2019). The contributions of UNESCO Man and Biosphere Programme and biosphere reserves to the practice of sustainability science. Sustainability Science, 14(3), 809-821. https://doi. org/10.1007/s11625-018-0603-0.

Richter-Beuschel, L., \& Bögeholz, S. (2020). Student teachers' knowledge to enable problem-solving for sustainable development. Sustainability, 12(1), 79. https://doi.org/10.3390/su12010079.

Riyadi, I. P., Prayitno, B. A., \& Karyanto, P. (2018). The effectiveness of subject specific pedagogy based on problem-based learning to empower student's ecological literacy. Cakrawala Pendidikan, 37(2), 212-222. https://journal.uny.ac.id/index. $\mathrm{php} / \mathrm{cp} /$ article/view/15809.

Saunders, M. N. K., \& Townsend, K. (2016). Reporting and justifying the number of interview participants in organization and workplace research. British Journal of Management, 27(4), 836-852. https://doi. org/10.1111/1467-8551.12182.

Straková, Z., \& Cimermanová, I. (2018). Critical thinking development-A necessary step in higher education transformation towards sustainability. Sustainability, 10(10), 3366. https://doi.org/10.3390/ su10103366.
Sunthonkanokpong, W., \& Murphy, E. (2019). Sustainability awareness, attitudes and actions: A survey of pre-service teachers. Issues in Educational Research, 29(2), 562-582. http://www.iier.org.au/iier29/ sunthonkanokpong-abs.html.

Suwarto, R. S., Sanjaya, Y., \& Solihat, R. (2021). Implementation of education for sustainable development and pupils' sustainability consciousness in Adiwiyata School and ESD-based school. Journal of Physics: Conference Series, 1806(1). https://doi.org/10.1088/1742$\underline{6596 / 1806 / 1 / 012153}$.

Tang, K. H. D. (2018). Correlation between sustainability education and engineering students' attitudes towards sustainability. International Journal of Sustainability in HigherEducation, 19(3), 459-472. https:// doi.org/10.1108/IJSHE-08-2017-0139.

Vasileiou, K., Barnett, J., Thorpe, S., \& Young, T. (2018). Characterising and justifying sample size sufficiency in interview-based studies: Systematic analysis of qualitative health research over a 15-year period. BMC Medical Research Methodology, 18(1), $\quad 148 . \quad$ https://doi.org/10.1186/ s12874-018-0594-7.

Wahono, B., \& Chang, C.-Y. (2019). Assessing teacher's Attitude, Knowledge, and Application (AKA) on STEM: An effort to foster the sustainable development of STEM education. Sustainability, 11(4), 950. https://doi.org/10.3390/su11040950.

Wu, Y. -C. J., \& Shen, J. -P. (2016). Higher education for sustainable development: A systematic review. International Journal of Sustainability in Higher Education, 17(5), 633-651. https://doi.org/10.1108/ IJSHE-01-2015-0004.

Zen, I. S. (2017). Exploring the living learning laboratory: An approach to strengthen campus sustainability initiatives by using sustainability science approach. International Journal of Sustainability in Higher Education, 18(6), 939-955. https:// doi.org/10.1108/IJSHE-09-2015-0154. 